\author{
Olga SOROCEAN ${ }^{1}$ \\ Neli DILAN ${ }^{2}$
}

\title{
SOCIO-ECONOMIC DYNAMICS OF CEE COUNTRIES WITHIN THE EUROPEAN UNION
}

\begin{abstract}
Integration processes are a growing trend in the global economy: the circle of participating countries is expanding; new forms and directions of international cooperation are appearing. The experience gained by the developing countries of Central and Eastern Europe proves the diversity of national models of participation in economic integration processes, as well as to the ambiguous results of their implementation. In order to ensure national competitiveness and security, it is necessary to ensure the diversification of the forms and directions of integration processes. The specifics and ambiguous consequences of the CEE countries development within the EU are of particular interest to developing countries located in close proximity to the borders of this integration association. The lessons of the integration association of Europe are in many respects valuable for Moldova, Belarus and Ukraine.
\end{abstract}

Keywords: CEE countries, integration processes, the socio-economic dynamics, specifics development, the economic development.

\section{INTRODUCTION}

Fundamental systemic transformations in the CEE countries and those from the postSoviet space determined the desire and participation of these states in the processes of European integration. Fifteen years after the large-scale enlargement of the EU, questions about the results of integration remain relevant both for the regional association as a whole and for the new members - transforming economies. The specifics and ambiguous consequences of the development of these countries within the EU are of particular interest to developing countries located in close proximity to the borders of this integration association.

\section{METHODOLOGY OF RESEARCH}

Research methods in the investigation and elaboration of the scientific approach have served: induction and deduction, logical analysis and synthesis, investigation method, analogy and comparison.

\footnotetext{
${ }^{1}$ Olga Sorocean, Doctor hab. of Economics, State University of Moldova, Department of Economics, Marketing and Tourism, Alexei Mateevici St 60, Chisinau; e-mail: olga_sorocean@ hotmail.com. ORCID: 0000-0001-6063-9293.

2 Neli Dilan, drd., State University of Moldova, Department of Economics, Marketing and Tourism, Alexei Mateevici St 60, Chisinau; e-mail: dilan.nelly@yahoo.com (corresponding author). ORCID: 0000-0001-6115-4984.
} 
The region of Central and Eastern Europe (CEE) began to transform from a historical and geographical concept into a geopolitical entity at the end of 1989. The question of which countries are part of it still remains open: there is no consensus on the identification of this region in international economic practice so far. Many international organizations include in the CEE region the former socialist states of Eastern Europe that are not members of the CIS. In addition, a number of researchers include, based on their accession to the European Union, CEE and the former Soviet Union republics: Latvia, Lithuania and Estonia (Grigas, 2013). Currently, 11 states with a transforming economy are EU members - these are Bulgaria, Hungary, Latvia, Lithuania, Poland, Romania, Slovakia, Slovenia, Croatia, Czech Republic and Estonia.

The effectiveness of integration, in accordance with the general scientific approach, can be determined by the ratio between the results achieved and the costs incurred. It is quite difficult to compare the various goals and results of the country's participation in various international integration projects, taking into account the short and long term, as well as the associated set of national costs - losses. Therefore, often, in order to assess the economic efficiency of European integration, individual macroeconomic indicators that most adequately reflect the socio-economic dynamics of the EU member states are used. Among them we can mention:

- annual GDP growth rate;

- level of national unemployment and migration;

- volume and geography of export and import;

- R\&D expenses.

Important features of the integration models of countries with transforming economies that have a fundamental impact on the consequences of EU enlargement are:

- focus on external sources of economic growth, mainly on capital inflows from developed EU countries;

- reorientation of national industrial production to the external market, and above all, to the EU market;

- integration of real sector enterprises into global value chains of European multinationals;

- offer of sufficiently qualified and cheap labour force.

By the time of accession to the EU, CEE countries, as a whole have successfully overcome the most difficult stage of socio-economic transformation and achieved macroeconomic stabilization. In the early years, the European Union experienced an economic boom in these countries caused by a combination of various factors. Among them:

- liberalization of trade and access to the European market,

- influx of advanced technologies and foreign direct investment from developed European countries,

- expansion of domestic demand,

- use of price and social dumping.

In the short term, the admission of new members to the EU had a positive effect on the overall dynamics of the EU's GDP, as the average growth rate in the "new" countries was higher than in the "old" countries. The highest growth rates were observed in the Czech Republic and Slovakia. In the "new" EU member states, per capita GDP increased significantly, by $8-12 \%$. Moreover, according to European experts, the access of the "new" 
EU countries to the pan-European market had a greater impact than the customs union and labour migration. Thus, the customs union and migration caused an increase in consumption by $1-2 \%$, while access to new markets - by $9 \%$.

In 2004, the year most CEE countries joined the EU, GDP growth was high in: Latvia $(8.3 \%)$, Lithuania (6.6\%), Estonia (6.3\%), Slovakia (5.3\%), Slovenia (4.4\%) and Hungary $(5.0 \%)$. The catalyst for the economic recovery was domestic demand, which grew due to higher wages and higher employment. In the Czech Republic, GDP, driven by domestic demand, peaked at 6.5\% in 2005, in Latvia - 10.7\%, and in Estonia - 9.4\% (table 1).

Table 1. GDP growth dynamics in CEE and the Eurozone, 2000-2018 (\%)

\begin{tabular}{|l|c|c|c|c|c|c|c|c|c|c|c|}
\hline & $\mathbf{2 0 0 0}$ & $\mathbf{2 0 0 1}$ & $\mathbf{2 0 0 4}$ & $\mathbf{2 0 0 5}$ & $\mathbf{2 0 0 8}$ & $\mathbf{2 0 0 9}$ & $\mathbf{2 0 1 2}$ & $\mathbf{2 0 1 3}$ & $\mathbf{2 0 1 6}$ & $\mathbf{2 0 1 7}$ & $\mathbf{2 0 1 8}$ \\
\hline $\begin{array}{l}\text { Czech } \\
\text { Republic }\end{array}$ & 4,3 & 2,9 & 4,9 & 6,5 & 2,7 & $-4,8$ & $-0,8$ & $-0,5$ & 2,5 & 4,4 & 2,9 \\
\hline Hungary & 4,2 & 3,8 & 5,1 & 4,4 & 0,9 & $-6,6$ & $-1,6$ & 2,1 & 2,3 & 4,1 & 4,9 \\
\hline Poland & 4,6 & 1,2 & 5,1 & 3,5 & 4,2 & 2,8 & 1,6 & 1,4 & 3,1 & 4,8 & 5,1 \\
\hline Slovenia & 4,2 & 2,9 & 4,4 & 4 & 3,3 & $-7,8$ & $-2,7$ & $-1,1$ & 3,1 & 4,9 & 4,5 \\
\hline Slovakia & 1,2 & 3,3 & 5,3 & 6,8 & 5,6 & $-5,4$ & 1,7 & 1,5 & 3,1 & 3,2 & 4,1 \\
\hline Romania & 2,5 & 5,2 & 10,4 & 4,7 & 9,3 & $-5,5$ & 2,1 & 3,5 & 4,8 & 7 & 4,1 \\
\hline Bulgaria & 4,8 & 3,8 & 6,4 & 7,1 & 6 & $-3,6$ & 0 & 0,5 & 3,9 & 3,8 & 3,1 \\
\hline Croatia & 3,8 & 3,5 & 3,9 & 4,1 & 2 & $-7,3$ & $-2,3$ & $-0,5$ & 3,5 & 2,9 & 2,6 \\
\hline Latvia & 5,4 & 6,5 & 8,3 & 10,7 & $-3,5$ & $-14,4$ & 4 & 2,4 & 2,1 & 4,6 & 4,8 \\
\hline Lithuania & 3,8 & 6,5 & 6,6 & 7,7 & 2,6 & $-14,8$ & 3,8 & 3,5 & 2,4 & 4,1 & 3,5 \\
\hline Estonia & 10,6 & 6,3 & 6,3 & 9,4 & $-5,4$ & $-14,7$ & 4,3 & 1,9 & 3,5 & 4,9 & 3,9 \\
\hline Eurozone & 3,9 & 2,2 & 2,3 & 1,7 & 0,5 & $-4,5$ & $-0,9$ & $-0,2$ & 1,9 & 2,4 & 1,9 \\
\hline
\end{tabular}

Source: compiled by the author based on World Bank data (http://www.worldbank.org).

The economic development of the countries of Central and Eastern Europe, which have demonstrated impressive economic growth and increasing well-being of the population since the beginning of the 2000 s, was interrupted by the global financial and economic crisis. The year 2009 was the most unfavourable year in the process of Euro-convergence of developing countries. For most of them, it took almost a decade to achieve pre-crisis indicators of GDP growth, and a number of countries (Baltic countries, Romania) were not able to restore high rates of development of the national economy.

The transition period in CEE countries, from the moment of their accession to the European Union, is considered completed, but this does not exclude the preservation of significant specifics, problems and difficulties in the functioning of national economies and institutions of the political organization of society.

The countries of the region are still experiencing serious economic problems, noticeably aggravated during the global financial and economic crisis. In the current conditions, the stable development of the economy is hampered by factors such as

- limited and inconsistent demand,

- weak investment activity,

- lack of internal resources for restructuring and modernization.

It is important to note that the economic lag of the "new" countries from the "old" in the EU was reduced not only due to the relatively rapid economic growth in most CEE 
countries, but also due to the growing crisis in developed European countries. Stagnation in the Eurozone, which has reduced the import needs of Western European companies, has turned for CEE countries to a sharp slowdown, and in some cases, a halt in export growth. As a result, in Romania, Croatia, Hungary, the Czech Republic, an economic recession was again noted, and the economy of Bulgaria, Slovenia came into a state of stagnation.

The average GDP growth rate in CEE countries in 2018 reached 4\%, which is twice as high as in the Eurozone (table 1), but is not sufficient to bring economies closer together. Despite some success on the path to reform, the gap between the countries of Central and Eastern Europe and the developed Western countries has not been reduced much. According to IMF forecasts, the total GDP of CEE in 2018-2022 will increase by no more than 3\% on average per year, lagging behind global economic growth.

Despite a significant share of 11 transforming CEE countries into the EU ( $40 \%$ of 28 countries in the regional block), their economic potential is insignificant: the combined GDP of these countries in 2017 amounted to only 8.5\% of EU GDP (table 2).

Table 2. Share of the country's GDP in the total GDP of the EU, 2017 (\%)

\begin{tabular}{|l|l|l|l|}
\hline Poland & 3,0 & Bulgaria & 0,3 \\
\hline Czech Republic & 1,3 & Croatia & 0,3 \\
\hline Romania & 1,2 & Lithuania & 0,3 \\
\hline Hungary & 0,8 & Latvia & 0,2 \\
\hline Slovakia & 0,6 & Estonia & 0,2 \\
\hline Slovenia & 0,3 & Total & $\mathbf{8 , 5}$ \\
\hline
\end{tabular}

Source: calculated and compiled by the author based on data from http://ec.europa.eu/eurostat.

At the same time, the largest contribution to the total GDP of the EU was made by Poland $-3 \%$, Czech Republic $-1.3 \%$, Romania $-1.2 \%$, Hungary $-0.8 \%$, which in general makes up two thirds of the total GDP of CEE. The remaining economies of this region are marked by scanty shares in the total EU GDP: Slovakia - 0.6\%, Slovenia, Bulgaria, Croatia and Lithuania $0.3 \%$ each, Latvia and Estonia $0.2 \%$ each.

One of the significant problems in the historical evolution of the EU was overcoming the gap between prosperous and lagging regions. However, with each new member of the European Union, it only increased. The great majority of the "new" CEE countries are poorer than the poorest EU members - 15. Of the 105 million people living in the new EU states, more than 98 million live in regions where per capita income is less than $75 \%$ of the average for the Union. In order to "pull up" lagging behind, a so-called "rapprochement policy" was carried out: funds were allocated from special rapprochement funds for structural transformations in the underdeveloped regions of the EU.

An acute socio-economic problem for many CEE countries, to some extent, was the outflow of the working population. The massive migration of labour from developing countries to the EU-15 exceeded all expectations. Short-term forecasts determined labour migration from East to West of Europe at the level of 300-350 thousand people in the early years of expansion. According to long-term forecasts, the total volume of labour migration was estimated at around 3 million people, that is, only $1.2 \%$ of the working population of the Eurozone in 2020. However, this forecast is far from true, according to the World Bank (table 3). 
Already the first years of CEE membership have shown that the percentage of labour force from these countries in the EU-15 markets is steadily increasing, especially after a restraining three-year transition period, indicated by some Western European countries (Great Britain, Austria and Ireland). The unemployment rate in the "new" EU countries has decreased not so much because of the increase in the number of employed, as because of the reduction in the number of working population (primarily their new generations), as well as because of significant emigration of citizens to Western Europe after the possibility of free, visa-free movement all-over the EU territory.

Table 3. Dynamics of labour migration from CEE countries, thousand people

\begin{tabular}{|l|c|c|c|c|c|}
\hline & $\mathbf{2 0 0 2}$ & $\mathbf{2 0 0 7}$ & $\mathbf{2 0 1 2}$ & $\mathbf{2 0 1 7}$ & $\begin{array}{c}\text { Population for 2018, } \\
\text { million }\end{array}$ \\
\hline Bulgaria & $-85,500$ & $-83,742$ & $-24,472$ & $-24,001$ & $7,024,216$ \\
\hline Czech Republic & 47,402 & 250,889 & 59,997 & 59,997 & $10,625,695$ \\
\hline Estonia & $-18,406$ & $-15,151$ & $-10,516$ & $-4,999$ & $1,320,884$ \\
\hline Hungary & 61,589 & 25,150 & 29,999 & 29,999 & $9,768,785$ \\
\hline Lithuania & $-99,104$ & $-150,930$ & $-146,217$ & $-25,000$ & $2,789,533$ \\
\hline Latvia & $-72,490$ & $-86,594$ & $-83,325$ & $-50,000$ & $1,926,542$ \\
\hline Poland & $-183,471$ & $-178,456$ & $-73,997$ & $-50,002$ & $37,978,548$ \\
\hline Romania & $-468,204$ & $-774,651$ & $-299,997$ & $-150,000$ & $19,473,936$ \\
\hline Slovakia & 1,199 & $-8,855$ & 11,346 & 4,999 & $5,447,011$ \\
\hline Slovenia & 14,998 & 39,348 & 16,571 & 6,002 & $2,067,372$ \\
\hline Eurozone & $6,731,514$ & $4,671,862$ & $1,929,664$ & $3,318,998$ & $341,783,171$ \\
\hline Croatia & $-2,580$ & $-10,499$ & $-32,772$ & $-40,000$ & $4,089,400$ \\
\hline
\end{tabular}

Source: compiled by the author based on data from the World Bank (http://www. worldbank.org).

The maximum outflow of the working population (more than 774 thousand people) was noted in Romania in 2007, when it joined the EU. In subsequent years, migration from Romania decreased, but the country still leads in this indicator in this region. A significant outflow of the population is also observed in the Baltic countries, especially in Lithuania and Latvia, if we take the indicator of the total population of these countries as a basis.

The gloomy situation with the population outflow is not observed in all countries of this region. The Czech Republic, Hungary, Slovenia, and Slovakia became attractive for the influx of labour force from European developing economies. In Poland, the outflow of labour resources is gradually decreasing, for comparison, if in 2002 more than 183 thousand people emigrated, in 2017 - only 50 thousand people (table 3 ).

The volume of labour migration from CEE is insufficient to significantly affect the structure and levels of wages in the EU labour markets. Of major concern in European recipient countries is migration from third countries. Currently, the population of the European Union is growing due to the influx from third countries, on average by 1 million people per year.

In most CEE countries, labour resources are reduced because of migration outflows and due to the population ageing, which in the near future will lead to a decrease in economic growth and an increase in budget deficits. 
A complex characteristic of the integration processes in the economy is the high share (more than 50\%) of mutual trade between the states of the integration association. The enlargement of the EU caused a steady increase in commodity flow, the share of intraregional trade in their total volume in almost all countries, which indicates the strengthening of trade relations with partners in the Union. At the same time, the enlargement led to a reduction in bilateral trade between old partners, fact which shows a slight weakening of trade relations between the countries that make up the core of the EU.

In the group of CEE countries (primarily in Hungary, Slovakia, the Czech Republic), output on the domestic market is declining. These countries have chosen an export-oriented development model. They are trying to fit into the global division of labour, entering foreign markets with their products and, at the same time, giving domestic markets to more competitive foreign goods. For some countries, namely Hungary, the Czech Republic, Slovakia and Slovenia, there is an increase in intra-industry trade with the EU countries (tables 4 and 5). For these countries is observed a narrowing of the gap with the EU-15 countries in industries with intensive use of skills, technologies and R\&D, while in Romania, Bulgaria and Poland this gap is not narrowing.

Table 4. The volume of exports of goods and services in CEE countries, \% of GDP

\begin{tabular}{|l|c|c|c|c|c|c|c|c|c|c|c|}
\hline & $\mathbf{2 0 0 0}$ & $\mathbf{2 0 0 1}$ & $\mathbf{2 0 0 4}$ & $\mathbf{2 0 0 5}$ & $\mathbf{2 0 0 8}$ & $\mathbf{2 0 0 9}$ & $\mathbf{2 0 1 2}$ & $\mathbf{2 0 1 3}$ & $\mathbf{2 0 1 6}$ & $\mathbf{2 0 1 7}$ & $\mathbf{2 0 1 8}$ \\
\hline Czech Republic & 48,2 & 49 & 57,3 & 62,2 & 63,2 & 58,7 & 76,2 & 76,9 & 79,6 & 79,7 & 78,8 \\
\hline Hungary & 66,7 & 64,7 & 59,5 & 62,5 & 79,3 & 74,4 & 86,4 & 85,7 & 89,7 & 88,2 & 86,5 \\
\hline Poland & 27,2 & 27,2 & 34,4 & 34,6 & 37,9 & 37,2 & 44,4 & 46,3 & 52,2 & 54,3 & 55,3 \\
\hline Slovenia & 50 & 51,7 & 55 & 59,6 & 66,1 & 57,2 & 73,1 & 74,5 & 77,8 & 82,9 & 85,2 \\
\hline Slovakia & 54,1 & 57,8 & 68,7 & 72 & 80 & 67,6 & 91,4 & 93,8 & 93,5 & 96,9 & 97,3 \\
\hline Romania & 21,6 & 22,1 & 25,7 & 24,5 & 26,2 & 26 & 37,4 & 39,9 & 41,2 & 41,5 & 41,6 \\
\hline Bulgaria & 36,5 & 35,1 & 41,3 & 42,9 & 52,5 & 42,3 & 60,8 & 64,9 & 64.0 & 67,4 & 64,5 \\
\hline Croatia & 36,5 & 38,7 & 39,5 & 39,4 & 38,5 & 34,5 & 41,5 & 42,7 & 48,7 & 51,1 & 51,2 \\
\hline Latvia & 36,9 & 38,1 & 39,1 & 43,2 & 39,5 & 42,6 & 61,3 & 60,3 & 60 & 61,1 & 58,9 \\
\hline Lithuania & 38,5 & 44 & 47,3 & 53,8 & 57,1 & 51,9 & 81,6 & 84,1 & 74,1 & 80.9 & 82,3 \\
\hline Estonia & 61,6 & 61,3 & 61,5 & 65,9 & 66,8 & 60,8 & 86 & 84,3 & 77,6 & 76.5 & 75,2 \\
\hline Eurozone & 35,3 & 35,3 & 35,1 & 36,4 & 39,8 & 34,9 & 43 & 43,2 & 44 & 45,4 & 45,8 \\
\hline
\end{tabular}

Source: compiled by the author based on data from the World Bank (http://www. worldbank.org).

Successful adaptation to the capacious and high-tech European market and its requirements has improved the position of EU newcomers in global markets in general. This group of countries began to actively use the EU's communitarian mechanisms to protect their positions in the Union's single internal market, as well as for economic expansion into the markets of third countries. Their share in world exports increased from 1\% in 1992 to $2.5 \%$ in 2018. On average, only the Czech Republic (+ EUR 10.5 billion), Hungary (+ EUR 4) and Poland (+EUR 3.6 billion) have deficit-free foreign trade and trade within the EU (http://dealerpride.ru/vnzh/the-countries-of-the-european-union-for-a-year-the-economy).

Assessing the results of the socio-economic transformation in CEE countries, we are bound to note a significant change in the geographical structure of the foreign trade of these states. The main trading partner for the countries of the region is the European Union 
(primarily Germany and France), which account for 50 to $70 \%$ of their foreign trade turnover. German firms have strengthened their integration ties with Poland, Slovakia, the Czech Republic, and Hungary. By organizing the production of certain parts and semifinished products in countries with cheap labour force, German companies significantly reduced their labour costs. This fragmentation of production allowed limiting wage growth in Germany and significantly increasing labour productivity (more than 20\%) (Евроинтеграция: влияние на экономическое развитие...). Bonuses for countries engaged in the production of components and integral parts to the West represent corresponding investments and a certain increase in jobs, however, with a significantly lower salary than in Germany.

Economic dynamics in Central and Eastern Europe in the near future will continue to depend on import demand in Western European markets, external sources of financing and cross-border flows of long-term business capital (table 5).

Table 5. The volume of imports of goods and services in CEE and the Eurozone, \% of GDP

\begin{tabular}{|l|c|c|c|c|c|c|c|c|c|c|c|}
\hline & $\mathbf{2 0 0 0}$ & $\mathbf{2 0 0 1}$ & $\mathbf{2 0 0 4}$ & $\mathbf{2 0 0 5}$ & $\mathbf{2 0 0 8}$ & $\mathbf{2 0 0 9}$ & $\mathbf{2 0 1 2}$ & $\mathbf{2 0 1 3}$ & $\mathbf{2 0 1 6}$ & $\mathbf{2 0 1 7}$ & $\mathbf{2 0 1 8}$ \\
\hline Bulgaria & 41.8 & 44.5 & 52.5 & 57.6 & 72.3 & 50.6 & 64.0 & 65.3 & 59.7 & 63.7 & 63.6 \\
\hline $\begin{array}{l}\text { Czech } \\
\text { Republic }\end{array}$ & 50.0 & 50.3 & 56.5 & 59.8 & 61.1 & 54.8 & 71.4 & 71.1 & 71.8 & 72.2 & 72.6 \\
\hline Estonia & 64.9 & 65.3 & 69.4 & 71.0 & 70.7 & 55.8 & 84.4 & 81.5 & 73.5 & 72.0 & 71.7 \\
\hline Hungary & 70.3 & 66.0 & 63.4 & 64.8 & 78.9 & 70.4 & 79.7 & 78.7 & 79.7 & 80.7 & 81.7 \\
\hline Lithuania & 44.7 & 49.5 & 54.4 & 61.1 & 68.7 & 53.6 & 80.8 & 82.8 & 72.8 & 78.1 & 79.7 \\
\hline Latvia & 44.9 & 48.4 & 54.6 & 57.7 & 52.5 & 44.2 & 65.8 & 63.9 & 58.8 & 61.0 & 59.5 \\
\hline Poland & 33.6 & 30.8 & 36.9 & 35.7 & 42.9 & 38.0 & 44.9 & 44.4 & 48.2 & 50.2 & 51.9 \\
\hline Romania & 26.9 & 29.8 & 34.9 & 34.8 & 39.0 & 32.4 & 42.5 & 40.7 & 42.1 & 43.7 & 44.9 \\
\hline Slovakia & 56.6 & 65.8 & 71.4 & 76.6 & 82.9 & 69.1 & 87.8 & 89.6 & 90.5 & 93.8 & 95.1 \\
\hline Slovenia & 53.7 & 52.8 & 56.4 & 60.2 & 68.0 & 55.4 & 68.9 & 69.0 & 68.6 & 73.2 & 75.7 \\
\hline Eurozone & 34.7 & 33.9 & 33.1 & 34.9 & 38.6 & 33.3 & 40.3 & 39.8 & 39.9 & 41.3 & 42.1 \\
\hline Croatia & 39.6 & 42.2 & 45.5 & 45.5 & 46.5 & 38.2 & 41.1 & 42.3 & 46.0 & 48.8 & 49.9 \\
\hline
\end{tabular}

Source: Compiled by the author based on data from the World Bank (http://www.worldbank.org).

The expansion of the freedom of movement of goods, capital and labour is indeed accompanied by an increase in economic activity, an increase in the similarity of economic structures, a convergence of prices for identical goods and services, an expansion of opportunities for competition and the adoption of skills, technologies, and experience. At the same time, the common European market does not supersede market forces, but, on the contrary, strengthens them.

The full opening of economy to foreign financial capital resulted in the virtually uncontrolled credit expansion of West European banks in the CEE region. The bulk of FDI was not in joint ventures, but in enterprises with $100 \%$ foreign participation, which are poorly integrated into the national economy.

The high openness of small transformable economies makes them particularly vulnerable against the backdrop of crisis situations in the global and European economies. 
Worsening of the economic situation, external factors that once contributed to their rise automatically turn into brakes.

The unified domestic market, trying to "catch up" the lagging participants, at the same time creates less favourable conditions for them than leaders. This forces the European Union to periodically integrate additional stimulants into the integration mechanism to improve the business and social environment, and to develop special measures as part of a common strategy or policy. Significant funds we received from the EU Funds, in the framework of regional policy, for the period 2007-2013 by such countries as: Estonia EUR 3.45 billion, Latvia - 4.6, Lithuania - 6.9, Slovakia - 11.6, Romania - 19.7, Hungary - 25.3, Czech Republic - 26.7, Poland - EUR 67.3 billion (Weresa, 2016).

It is important to emphasize that unevenness is inherent in a market economy and, within reasonable limits, is a stimulator of development. Therefore, the European Union does not aim at full equalization and does not transfer the problems of certain regions and categories of the population to the supranational level of government. In fact, the EU is limited to those methods that do not reduce the effectiveness of the market system. When allocating funds, the European Commission adheres to the principle of common benefits: money is allocated for specific projects in which the European Union is interested.

The intervention of the European Union in the implementation of a task, according to the principle of subsidiarity, occurs when the expected final effect requires it. The essence of the concept of subsidiarity is that only those issues that cannot be resolved at a lower level should be brought to the highest level of management. Subsidiarity is declared as one of the normative postulates of European integration. National expenditures are replaced by community expenses if the goals of the Union cannot be sufficiently implemented by individual countries and are only successfully achieved at EU level. This mainly happens when financing activities within the framework of a common agricultural policy.

The lessons of the integration association of Europe are in many respects valuable for other developing countries, in the context of their ever-opening global economic environment. Moreover, the influence of the integration process components on the development of lagging members of the group is for the most part contradictory; it cannot be unambiguously defined as positive or negative.

Distinctive features of the socio-economic dynamics of the CEE countries are:

- high level of openness of economies;

- increasing dependence of the socio-economic development of these countries on developed partners for EU integration association;

- focus on external sources of economic growth;

- outflow of labour force;

- reorientation of production from the domestic market to the external one.

CEE countries, despite the obvious successes, are still far from fulfilling the conditions of monetary convergence, according to which the inflation rate and interest rates should be within strict boundaries of the average level of the three member countries of the Union, which have the most stable prices and a stable exchange rate. This implies joining the European system of currency regulation and the inability for two years to exceed the boundaries of the maximum limits of variation (maintaining inflation below $3 \%$ and interest rates below $9 \%$ ).

The convergence between Western and Central Europe, as well as between Eastern and South-eastern Europe, however, may take longer than anticipated. This is because in the 
longer term, the growth potential (maximum acceptable production growth expected in the economy) in most European countries is still significantly lower than before the global financial crisis.

With the further development of the CEE countries, the national identity of each of them will grow. Each country faces a unique "set" of problems and needs. The tasks and difficulties that arise in the Czech Republic, Estonia or Slovenia, in their dimension, type and level, are sharply different from the problems of Romania or Poland. Therefore, it is impossible to propose a single "average" development project for all CEE countries.

It is important to note that any integration activity under the influence of many factors, circumstances and interests is interrupted by various disintegration trends (the collapse of the USSR, Brexit, and the transformation of GUUAM into GUAM). It is the interaction of convergent and divergent vectors that acts as an internal source of development and European integration. Moreover, under adverse conditions, "centrifugal" forces clearly prevail over "centripetal" forces.

CEE countries set similar goals and used basically the same approaches and instruments of integration policy. However, despite this, over the past years they have not been able to achieve equally successful results (table 6). The reason for this was both different starting conditions, and miscalculations, errors of leaders that were governing the country. In many respects, the determining factor in the success of a particular sector of the economy was foreign investment, combined with government policy in creating the necessary climate and legal framework for investor interaction. In the foreseeable future, the economic dynamics in Central and Eastern Europe will continue to depend to a decisive extent on the demand for imports in Western European markets, external sources of financing, and cross-border flows of long-term business capital.

Table 6. Classification of CEE and Eastern Europe by income, GNI / per capita in 2018, according to World Bank criteria (https://blogs.worldbank.org/opendata/...)

\begin{tabular}{|c|c|}
\hline $\begin{array}{l}\text { High-income countries, } \\
>\text { USD } 12055\end{array}$ & $\begin{array}{l}\text { Upper middle income countries, } \\
\text { USD 3996-12375 }\end{array}$ \\
\hline $\begin{array}{ll}\text { Slovenia............ } & 24580 \\
\text { Estonia ........... } & 21140 \\
\text { Czech Republic.... } & 20240 \\
\text { Slovakia ........... } & 18260 \\
\text { Lithuania.......... } & 17430 \\
\text { Latvia............. } & 16510 \\
\text { Hungary........... } & 14780 \\
\text { Poland............. } & 14100 \\
\text { Croatia ............ } & 14000\end{array}$ & $\begin{array}{l}\text { Romania } \ldots \ldots \ldots \ldots \ldots \\
\text { Bulgaria } \ldots \ldots \ldots \ldots \ldots\end{array}$ \\
\hline $\begin{array}{c}\text { Lower-middle-income countries, } \\
\text { USD 1026-3995 }\end{array}$ & Low Income Countries, < USD 1026 \\
\hline $\begin{array}{l}\text { Moldova } \ldots \ldots \ldots \ldots . \ldots 2980 \\
\text { Ukraine ............ } 2660\end{array}$ & $* * * * *$ \\
\hline
\end{tabular}

Source: compiled by the author on the basis of the analytical classification and the World Bank database (http://www.worldbank.org/ The World Bank: Gross National Income per Capita 2018). 
New EU countries today, as never before, are far from the Maastricht criteria for monetary convergence, the compliance with which is a prerequisite for joining the currency union. This applies to inflation, to interest rates, budget deficits, and, in the case of Hungary, to public debt (more than 70\% of GDP).

So, the processes of European economic integration are ambiguous in their consequences. Countries that play a leading role in regional unions have more positive than negative effects of integration. For less developed countries, the situation is reversed. Therefore, the euphoria and rainbow myths are being replaced by a critical assessment of European integration as an internally contradictory phenomenon, with a serious opposition to the interests of players.

In order to ensure national competitiveness and security, it is necessary to ensure the diversification of the forms and directions of integration processes. Only balanced, taking into account national interests, decisions and actions with partners on integration projects can ensure real promotion of countries with emerging markets.

\section{REFERENCES}

Eurostat electronic database [Electronic resource] URL. Access on the internet: http://ec.europa.eu/eurostat.

Grigas, A. (2013). The baltic states in the eu: yesterday, today and tomorrow. Studies \& reports, july.

Guerrieri, P. (2012). Intra-European Imbalances: the Need for a Positive-sum-game Approach. International Economics, and December.

http://dealerpride.ru/vnzh/the-countries-of-the-european-union-for-a-year-the-economy.

https://blogs.worldbank.org/opendata/new-country-classifications-income-level-2019-2020.

https://data.worldbank.org/indicator/NY.GNP.PCAP.CD.

Weresa, M.A. (2016). Competitiveness report 2016 the role of economic policy and institutions. Warsaw: Copyright by the Warsaw School of Economics.

World Bank Group/ Всемирный банк. Access on the internet: http://www.worldbank.org.

Глинкина, С.П., Куликова, Н.В., Синицина, И.С. (2014). Страны Центрально-Восточной Eвponbl: евроинтеграция и экономический рост.- Москва. Институт экономики.

Евроинтеграция: влияние на экономическое развитие Центральной и Восточной Европы. Доклады Института Европы. № 303. М., 2014.

DOI: 10.7862/rz.2020.mmr.9

The text was submitted to the editorial office: March 2020.

The text was accepted for publication: March 2020. 